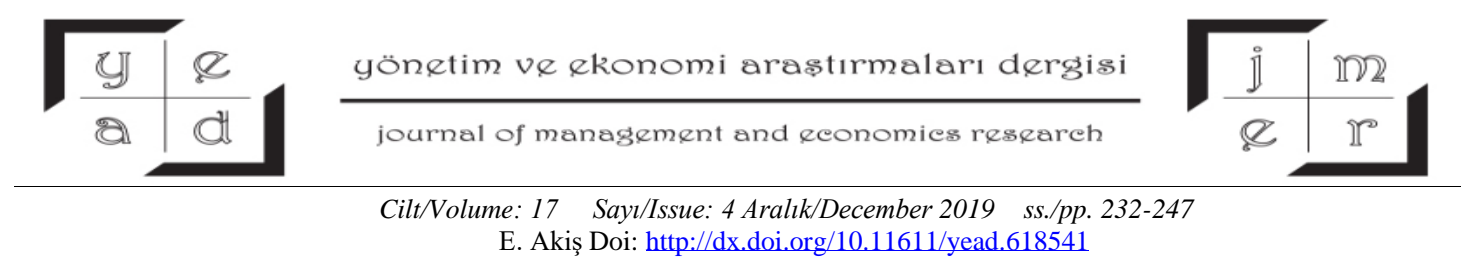

\title{
TÜRK BEYAZ EŞYA SANAYIII'NIN REKABET GÜCÜ
}

\section{Dr. Öğr. Üyesi Elife AKİș *}

\section{ÖZET}

Dünya ticaretinde bilgi ve teknolojiye dayalı yüksek katma değerli sektörlerin aldı̆̆ artmaktadır. Orta üst teknoloji düzeyine sahip Beyaz eşya sektörü ülkemizi uluslararası ölçekte temsil eden önde gelen sektörlerden biridir. Çalışmada, 2008 - 2017 yılları arasında Türk Beyaz Eşya Sanayii'nin rekabet gücünün ve sürdürebilirliğinin belirlenmesi amaçlanmıştır. Bu amaç doğrultusunda ilk olarak Dünya beyaz eşya sanayiinin genel yapısı ve Türk beyaz eşya sanayii incelenerek, rekabet gücü ve Açılklanmış Karşılaştırmalı Üstünlükler Endeksi açıklanmıştır. Son olarak da Türk beyaz eşya sanayiinin rekabet gücü analizi, Balassa’nın “Açıklanmış Karşılaştırmalı Üstünlükler Endeksi” ne göre yapılmıştır. Yapılan hesaplamaların sonucuna göre toplam beyaz eşya sektörü ve ürün gruplarının endeks değeri l'den büyük çıkmıştır ve dolayıslyla Türk beyaz eşya sanayii rekabet gücüne sahiptir. Sektörlere Sanayi 4.0'ın yön verdiği günümüzde, dünya piyasasında daha etkin yer almak için sektörün rekabet gücünü devam ettirirken firmaların, katma değeri daha yüksek, yoğun bilgi ve Ar-Ge yatırımı gerektiren, ileri teknolojili ürünlere ağıllk vermeleri ve Sanayi 4.0 dönüşümüne uyum sağlamaları gerekmektedir.

Anahtar Kelimeler: Rekabet Gücü, Açıklanmış Karşılaştırmalı Üstünlükler, Türk Beyaz Eşya Sanayii.

JEL Kodlart: E01,E20, O14, L68, F40.

\section{COMPETITIVENESS OF TURKISH WHITE GOODS INDUSTRY}

\begin{abstract}
The share of high value-added sectors based on information and technology in world trade is rapidly increasing. White goods sector, which has medium-high technology level, is one of the leading sectors representing our country on an international scale. The aim of this study is to determine the competitiveness and sustainability of Turkish White Goods Industry between 2008-2017. In line with this purpose, firstly, the general structure of the world white goods industry and the Turkish white goods industry were reviewed and the competitiveness and the Revealed Comparative Advantages Index was explained. Lastly, the competitiveness analysis of the Turkish white goods industry was analyzed according to the Balassa Revealed Comparative Advantages Index. According to the results of the
\end{abstract}

* İstanbul Üniversitesi İktisat Fakültesi İktisat Politikası Anabilim Dalı, İstanbul/Türkiye, e-mail: elifakis@istanbul.edu.tr

\section{Makale Geçmiși/Article History}

Başvuru Tarihi / Date of Application : 2 Eylül / September 2019 
calculations, the index value of the total white goods sector and product groups was greater than 1. Therefore, Turkish white goods industry has competitive power. While Industry 4.0 is leading the sectors today, in order to be more effective in the world market, companies need to concentrate on advanced technology products that require high value added, intensive knowledge and $R \& D$ investments and adapt to the Industry 4.0 transformation and maintain the competitiveness.

Key Words: Competitiveness, Revealed Comparative Advantages, Turkish White Goods Industry.

JEL Codes: E01, E20, O14, L68, F40.

\section{GíRiş}

Farklı teknolojileri sebebiyle çok geniş bir ürün yelpazesine sahip olan Beyaz Eşya Sektörü, elektrikli ev aletleri ve aynı zamanda dayanıklı tüketim malları kapsamına giren; buzdolabı, derin dondurucu, çamaşır makinesi, kurutma makinası, bulaşık makinesi ve fırın olmak üzere altı ana ürün kapsamında değerlendirilmektedir.

Türk beyaz eşya sektörü; yüksek katma değeri, güçlü ihracat hacmi, rekabet gücü ve bilinirliği yüksek markalarıyla ülkemizi uluslararası ölçekte temsil eden önde gelen sektörlerden biridir. Avrupa'nın en büyük, dünyanın ise en büyük ikinci üreticisi konumundadır. Sektör üretiminin dörtte üçünü başta $\mathrm{AB}$ ülkeleri olmak üzere 150'yi aşan ülkeye ihraç ederek ülke ekonomisine önemli döviz girdisi sağlamaktadır. Ayrıca sektör doğrudan yaklaşık 60.000 kişiye istihdam sağlamakla birlikte, sektörün gelişimine paralel olarak büyüyen tedarik zinciri, yan sanayi ve bayi ağı ile birlikte yarım milyonu aşmaktadır.

$\mathrm{Bu}$ çalışmanın amacı Rekabet gücü kavramını açıkladıktan sonra Türkiye ekonomisine ciddi katkıları olan beyaz eşya sanayiinin rekabet gücünü analiz etmektir. Rekabet gücünü ölçmek için Balassa'nın geliştirdiği Açıklanmış Karşılaştırmalı Üstünlükler (AKÜ) yaklaşımı kullanılacaktır.

Birleşmiş Milletler'in veri tabanından elde edilen veriler doğrultusunda 2008-2017 yılları arasında Türkiye'nin beyaz eşya sanayiinin toplam ve seçilmiş ürünlerinin (ev tipi buzdolapları, ev tipi derin dondurucular, ev tipi çamaşır makineleri, Ev tipi bulaşık yıkama makineleri ve bütün bu ürünlerin de yer aldığı elektrikli ve elektriksiz ev aletleri ürünleri) rekabet gücü, Balassa'nın Açıklanmış Karşılaştırmalı Üstünlükler Endeksi(AKÜ)'ne göre analiz edilecektir. Birleşmiş Milletler'in veri tabanından Fırın, Mikro Dalga Fırın ve Diğer Pişiriciler ile ilgili veriler çekilemediği için bu ürün grubunun analizi yapılamamıştır.

\section{BEYAZ EŞYA SANAYIIININ TANIMI ve SINIFLANDIRILMASI}

Dayanıklı tüketim malları alt sektörlerinden biri olan Beyaz Eşya Sektörü, genel olarak elektrikli ev aletleri üretiminde; buzdolabı, fırın, çamaşır makinesi, bulaşık makinesi gibi ürünlerin yer aldığı bir alt grubu oluşturmaktadır. Bu nedenle beyaz eşya sektörü, dayanıklı tüketim malları kategorisine giren 
ürünlerin imalatını gerçekleştirmektedir. Ev aletleri sektörünü ise bazı alt sektörlere ayırmak mümkündür. En yaygın ayrım beyaz eşya - kahverengi eşya gruplamasıdır. Bu sınıflamaya göre:

- Kahverengi eşya sektörü; televizyon, müzik seti, kaydedici ve okuyucu video cihazları gibi “tüketici elektroniği” kategorisine giren ürünleri kapsamaktadır.

- Beyaz eşya sektörü ise; başlıca buzdolabı, çamaşır makinesi, bulaşık makinesi ve firınlar gibi evlerde kullanılan diğer ürünlerden oluşmaktadır.

Beyaz eşya sanayii istatistikleri daha önce temel beyaz eşya ürünleri ve küçük ev aletleri olarak iki değişik sınıf içinde takip edilirken, 1997 yılından itibaren yeni bir faaliyet sınıflaması olan ISIC(International Standard Industrial Classification of All Economic Activities) Rev3'de, dördüncü ayrınt1 düzeyinde, 2930 sınıfı kapsamı içinde izlenmektedir. Daha önce kullanılan ISIC-Rev2 sınıflamasında, temel beyaz eşya ürünleri 3829 kodlu "Diğer makineler" alt sınıfı kapsamında, altıncı ayrıntı düzeyinde, ürün grubu esasına göre takip edilmekteydi. ISIC-Rev2 3833 sınıfi kapsamında ise "Elektrikli Ev Aletleri" bulunmaktaydı. Ayrıca 2002 yılından itibaren NACE-Rev1 (Statistical Classification of Economic Activities in the European Community)'de de 2971 kod ile "Elektrikli ev aletleri imalatı" sinıfında yer almaktadır. STIC (Standard International Trade Classification) Rev.3'e göre ise 775 kod ile "Evlerde Kullanılan Makineler (Çamaşır makinesi, buzdolabı, bulaşık makinesi vb.)" grubunda takip edilmektedir.

Bu çalışmada, beyaz eşya sanayi, STIC-Rev.3 sınıflamasındaki 775 kodlu "Evlerde kullanılan makineler (Çamaşır makinesi, buzdolabı, bulaşık makinesi vb.)” grubu olarak ele alınmıştır.

SITC Rev.3 (1988); SITC (1951), SITC Rev.1 (1961) ve SITC Rev.2 (1975) sinıflamaların güncelleştirilmiş versiyonudur. Birleşmiş Milletler tarafindan yayınlanan bir uluslararası ticari mal siniflandirmasidir.

\section{DÜNYA'DA BEYAZ EŞYA SANAYIII}

Beyaz eşya sektörü yüksek yatırım ihtiyacı, teknoloji ve işlevsellik açısından üreticilerin sürekli rekabeti, marka bilinirliliğinin önem taşıması gibi faktörler sebebiyle az sayıda firmanın yer aldığı oligopol yapıya sahip bir piyasadır (Öz ve Pamuksuz, 2003: 2).

Beyaz eşya üreticilerinin son yıllarda yeni pazarlara doğrudan girmek yerine nihai pazarda marka bilinirliği yüksek firmalarla ortaklık kurduğu veya satın aldığı ve bu markaların kullanımına devam ettiği görülmektedir. Şirket birleşme ve satın almalarının öncelikli motivasyonları olarak ölçek ekonomisi ile verimlilik artışı, yeni pazarlara ulaşma ve hedef şirketlere ait markaların bilinirliğinden faydalanma öne çıkmaktadır. Ayrıca marka bilinirliği, tüketici tercihini etkileyen ürün kalitesi ve fonksiyonellik gibi öncelikli unsurlardan hemen sonra gelen önemli faktörlerden biridir (Avcığlu, Özata, Nirun ve Gürel 2018: 6-7). 
ABD merkezli Whirlpool firması pazar payını arttırmakta zorluk yaşadığı Avrupa pazarında, İtalya merkezli İndesit şirketini satın alarak küresel varlığını güçlendirmiştir. Şirket birleşmesi planlarının gerçekleşmesinde, piyasadaki rekabeti bozucu ya da tekelci sayılan işlemleri kısıtlayan (antitröst) uygulamalar da önemli rol oynamaktadır.

2016 yılı ciro bilgileri ışığında zirvedeki altı üretici Çin'den Media Group (24.9 milyar dolar), Çin'den Haier Group (18.6 milyar dolar), Amerika merkezli Whirlpool (18.6 milyar dolar), Çin'den Gree (17.7 milyar dolar), İsveçli Electrolux (13.9 milyar dolar) ve Alman Bosch Siemens Hausgerate (13.5 milyar dolar)'dir. Ülkemizden Arçelik ise 5,5 milyar dolar ile yedinci sırada yer alarak Almanya'dan Miele (2,9 milyar dolar) ve İsviçre'den Franke (2,1 milyar dolar)'yi geride bırakmıştır. Küresel ölçekte faaliyet gösteren bu şirketlerin çoğu beyaz eşyanın yanı sıra başta küçük ev aletleri olmak üzere, klima, TV ve diğer elektronik cihazların da üretimini gerçekleştirmektedirler (Avcığlu, Özata, Nirun ve Gürel 2018: 6).

Küresel beyaz eşya ihracatı 2016 y1lında 100 milyar dolar iken 2017 yılında 96 milyar dolara gerilemiştir. İhracatın ürün dağılımına bakıldığında 16 milyar dolar ile ev tipi buzdolabının ilk sırada olduğu, 8 milyar dolar ile ev tipi çamaşır makinesinin ikinci sırada olduğu, 4 milyar dolar ile ev tipi bulaşık makinesinin onu izlediği ve son olarak da yaklaşık 3 milyar dolar ile ev tipi derin dondurucunun yer aldığ1 görülmektedir (https://comtrade.un.org/data/, 10.07.2019).

Dünya mal ihracatı 2008 küresel krizinden sonra azalmış ve ancak 2011 yılından itibaren 2008 seviyesini aşabilmiştir. 2014 y1lından sonra tekrar düşüş trendine girmiş hatta 2016 y1lında 2008 yılı seviyesinin de altına düşmüş ve 2017 yılında tekrar yükselişe geçmiştir. Dünya beyaz eşya sanayii ihracatına baktığımızda da benzer gelişmeleri görmekteyiz. Ancak Dünya mal ihracatının aksine küresel beyaz eşya ihracatı 2016 yılında artış gösterirken 2017 yılında düşüşe geçtiği görülmektedir. (Tablo 1)

Tablo 1: Dünya'da Mal ve Toplam Beyaz Eşya İhracatı - İthalatı

\begin{tabular}{|c|c|c|c|c|c|c|c|c|}
\hline Yillar & $\begin{array}{c}\text { Dünya Mal } \\
\text { İhracatı ( bin } \\
\$ \text { ) } \\
\end{array}$ & $\begin{array}{c}\text { Büyüme } \\
\text { Hızı } \\
(\%)\end{array}$ & $\begin{array}{c}\text { Dünya Mal } \\
\text { İthalatı ( bin } \\
\$ \text { \$) } \\
\end{array}$ & $\begin{array}{c}\text { Büyüme } \\
\text { Hızı } \\
(\%)\end{array}$ & $\begin{array}{c}\text { Dünya Beyaz } \\
\text { Eşya İhracatı } \\
\text { (bin \$) }\end{array}$ & $\begin{array}{c}\text { Büyüme } \\
\text { Hızı } \\
(\%)\end{array}$ & $\begin{array}{c}\text { Dünya Beyaz } \\
\text { Eşya İthalatı } \\
\text { (bin \$) }\end{array}$ & $\begin{array}{c}\text { Büyüme } \\
\text { Hızı } \\
(\%) \\
\end{array}$ \\
\hline 2008 & \begin{tabular}{|l}
15.715 .302 .498 \\
\end{tabular} & & \begin{tabular}{|l|}
16.094 .228 .309 \\
\end{tabular} & & 86.010 .168 & & 87.840 .390 & \\
\hline 2009 & \begin{tabular}{|l}
12.269 .635 .881 \\
\end{tabular} & $-21,93$ & \begin{tabular}{|l}
12.384 .737 .407 \\
\end{tabular} & $-23,05$ & 73.942 .058 & $-14,03$ & 75.153 .032 & $-14,44$ \\
\hline 2010 & 5.034 .673 .350 & 22,54 & \begin{tabular}{|l}
15.164 .948 .531 \\
\end{tabular} & 22,45 & 84.908 .040 & 14,83 & 87.756 .299 & 16,77 \\
\hline 2011 & \begin{tabular}{|l|l}
17.999 .854 .646 \\
\end{tabular} & 19,72 & \begin{tabular}{|l}
18.069 .871 .577 \\
\end{tabular} & 19,16 & 94.319 .105 & 11,08 & 96.191 .724 & 9,61 \\
\hline 2012 & \begin{tabular}{|l}
17.968 .920 .160 \\
\end{tabular} & $\begin{array}{l}-0,17 \\
\end{array}$ & \begin{tabular}{|l}
18.121 .311 .079 \\
\end{tabular} & 0,28 & 95.779 .458 & 1,55 & 97.030 .065 & $\mathbf{0 , 8 7}$ \\
\hline 2013 & \begin{tabular}{|l}
18.708 .874 .043 \\
\end{tabular} & 4,12 & 18.565 .534 .505 & 2,45 & 101.757 .819 & 6,24 & 101.372 .509 & 4,48 \\
\hline 2014 & 18.610 .406 .812 & $-0,53$ & 18.537.279.917 & $-0,15$ & 106.262 .428 & 4,43 & 105.641 .550 & 4,21 \\
\hline 2015 & \begin{tabular}{|l|}
16.115 .931 .369 \\
\end{tabular} & $-13,40$ & \begin{tabular}{|l|}
16.160 .302 .265 \\
\end{tabular} & $-12,82$ & 99.292 .969 & $-6,56$ & 99.768 .542 & $-5,56$ \\
\hline 2016 & 15.672 .244 .352 & $-2,75$ & \begin{tabular}{|l}
15.719 .984 .546 \\
\end{tabular} & $-2,72$ & 100.264 .114 & 0,98 & 100.957 .637 & 1,19 \\
\hline 2017 & \begin{tabular}{|l|}
16.915 .622 .084 \\
\end{tabular} & 7,93 & \begin{tabular}{|l|}
17.256 .821 .240 \\
\end{tabular} & 9,78 & 96.334 .325 & $-3,92$ & 97.592 .179 & $-3,33$ \\
\hline
\end{tabular}

Kaynak: Birleşmiş Milletler'in verilerinden oluşturulmuştur. (https://comtrade.un.org/data/, 10.07.2019).

Tablo 1'den de anlaş1lacağ gibi 2009 yılında 2008 küresel krizinin etkisi sonucu dünya mal ticareti yaklaşık \%22 civarında küçülmüştür. Buna paralel olarak dünya beyaz eşya ticaretinde de \%14'lük bir düşüş yaşanmıştır. 2010 ve 2011 yıllarında gerek dünya mal ticareti gerekse dünya beyaz 
eşya ticareti krizin etkisinden sıyrılarak tekrar büyüme kaydetmiştir. 2012 yılından sonra ise küresel dış ticaret yeniden daralmaya başlamış sonrasında büyüme kaydedilen yıllarda da büyüme oranları tatmin edici seviyede olmamıştır. 2012 - 2017 yılları arasında Dünya beyaz eşya ticareti mal ticaretine oranla pozitif büyümeye küçük oranlarda da olsa devam etmiştir. Hatta 2013 yılında mal ticaretinden daha yüksek oranda büyümüştür. 2015 yılında hem dünya mal ticareti hem de beyaz eşya ticareti daralmış iken 2016 ve 2017 yıllarında farklı bir gelişme olmuştur. 2016 yılında dünya mal ticareti daralırken beyaz eşya ticareti artmış, 2018 yılında ise dünya mal ticareti büyürken beyaz eşya ticareti daralmıştır.

Lider beyaz eşya ihracatçıları Çin, Almanya, Polonya, Türkiye, İtalya, Tayland, ABD, Meksika, İspanya ve Güney Kore'dir. Türkiye 2012 yılında beşinci sırada yer alırken 2014 yılından itibaren İtalya'yı geçerek dördüncü sırada yer almaktadır. Çin, Polonya ve Türkiye'nin dolar bazında ihracatı artarken İtalya, İspanya, Amerika ve Meksika'nın ihracatında gerileme izlenmiştir (https://comtrade.un.org/data/, 10.07.2019).

Dünya beyaz eşya ithalatı incelendiğinde en çok ithalat yapan ilk on ülkenin gelişmiş ekonomilerden oluştuğu görülmektedir. Önde gelen ithalatçı ülkeler arasında Amerika, Almanya, İtalya ve İsveç'in ithalatında son beş yılda artış izlenirken, Fransa, Japonya, Avustralya ve Hollanda'da gerileme görülmektedir (https://comtrade.un.org/data/, 10.07.2019).

Gelişmiş ülkelerde yeniden satın alma ve mevcut ürünün daha yeni teknolojiye sahip olan ürünle değiştirilmesi sonucunda büyüyen Beyaz eşya sektörü, gelişmekte olan ülkelerde ise yaygınlık oranlarının nispeten düşük ve yaşam standartlarının yükselme eğiliminde olduğundan ilk kez beyaz eşya sahibi olmaya yönelik satışlarla büyümektedir (Öztürk, 2016;7).

\section{TÜRK BEYAZ EŞYA SANAYIİ}

Çalışmanın bu bölümünde Türk beyaz eşya sanayiinin tarihsel gelişimi, ekonomik yapısı, beyaz eşya talebini etkileyen faktörler üzerinde durulmuştur.

\subsection{Türk Beyaz Eşya Sanayii'nin Tarihsel Gelişimi}

Temelleri 1950'li y1llarda atılan Türk beyaz eşya sektörü, ilk üretimini 1959 yılında Arçelik Sütlüce Fabrikası'nda çamaşır makinesinde gerçekleştirilmiştir. 1960 yılında ise yine aynı fabrikada buzdolabı da üretilmeye başlanmıştır. Yerli sanayinin henüz kuruluş safhasında olduğu bu dönemlerde, teknik imkânların ve de talebin kısıtlı olması nedeniyle üretim yüksek miktarlarda gerçekleşememiştir. 1965 yılında toplu iğne imalatına başlanıldığ ve sanayimizin yeni yeni atılım içerisinde olması düşünülecek olursa; Türk Beyaz Eşya Sanayiinin 1959'da Çamaşır Makinesi, 1960'da Buzdolabı, 1963'de Fırın, 1965'de Elektrik Süpürgesi ve Santrifüjlü Yarı Otomatik Çamaşır makinesi üretmeye başlaması Beyaz Eşya sanayinin öncülüğünü daha da önemli kılmaktadır (Öztaşkın, 2007: 87).

Ülkenin montaj hatlarından 1960'da çıkan ilk buzdolabı, İsrailli Amcor şirketinin lisansıyla üretilmiştir. Aynı yıl Profilo, AEG lisansıyla buzdolabı imalatına başlamıştır. 1970 ile 1976 yılları 
arasında, bebek endüstri argümanıyla endüstri ithal rekabetten korunmuş ve Arçelik ile Profilo 1980'lere kadar Türkiye pazarına hakim olmuştur. İthalatın aşamalı olarak serbestleşmesi 1980’lerde başlatılmış, bununla birlikte ithal beyaz eşya talebi de canlanmıştır. 1996'da AB ile yapılan Gümrük Birliği'yle birlikte $\mathrm{AB}$ ürünleri için tüm ithalat engelleri kaldırılmış ve üçüncü taraf ülkelere $\mathrm{AB}$ 'nin daha düşük gümrük tarife oranları uygulamaya girmiştir. 1990'larda dikkate değer bir başka gelişme de iki büyük Avrupalı üreticinin, Merloni'nin (ilk olarak Vestel ile) 1994'te, BSHG'nin (Profilo ile) 1995'te Türkiye piyasasına girmesidir (Öz ve Pamuksuz, 2003: 2).

Başlıca fabrikaları İstanbul, Manisa, Eskişehir, Bolu, Gebze, Bursa, İzmir, Kocaeli, Yalova, Kırklareli, Kayseri, Konya ve Bilecik’te yer alan sektörün imalatı daha çok Marmara, Ege ve Orta Anadolu'da yoğunlaşmıştır. Sektörde 6 büyük beyaz eşya üreticisi ile birlikte 50 'nin üzerinde orta ölçekli imalatçı ve 1000'in üzerinde aksam ve parça imalatçısı faaliyet göstermektedir.

Şu anda Türkiye'de Arçelik, BSH, Candy Group, Demirdöküm, Vestel ve Silverline olmak üzere 6 büyük beyaz eşya üreticisi bulunmakta ve bu üreticiler Altus, Arçelik, Beko, Bosch, Candy, Esty, Silverline, Süsler, Demirdöküm, Vestel ve Vestfrost markaları ile piyasaya ürün sunmaktadırlar. Bu 6 beyaz eşya üreticisi de “Türkiye Beyaz Eşya Sanayicileri Derneği- TÜRKBESD” üyesidirler. Yan sanayi grubunda yer alan 200 kadar firma da "Beyaz Eşya Yan Sanayicileri Derneği-BEYSAD" çatıs1 altında toplanmıştır (http://www.turkbesd.org/uyeler.php, 15.07.2019)

Her geçen gün artan üretimi, gelişen teknolojisi, ihracat kapasitesi ve tüm bunlara bağl1 olarak büyüyen yan sanayi, bayi ağları, servis ve istihdam imkânları açısından beyaz eşya sektörünün, Türkiye ekonomisine olan katkısı çok önemli boyutlara ulaşmıştır. Bu çerçevede beyaz eşya sektörü doğrudan neredeyse 60.000 kişiye istihdam sağlamakla birlikte, söz konusu sayı fabrikaları, yan sanayileri, bayi ve servis teşkilatlarıyla yaklaşı 500.00 kişiyi aşmaktadır (http://www.turkbesd.org/bilgiler.php, 15.07.2019).

Türkiye ekonomisinin lokomotif sektörleri arasında olan beyaz eşya sektörünün büyümesinde gelişmiş teknolojisi, inovatif yapısı, sağladığı ihracat geliri ve yarattığı istihdam ile birlikte, şehirleşme oranının ve genç nüfusun artması ve inşaat sektöründeki hareketlilik etkili olmaktadır. 2015 yılında 6 ana ürün sınıfında 3 milyar dolarlık ihracat gerçekleştiren sektörde, üretimin dörtte üçü başta AB ülkeleri olmak üzere yaklaşık 150 ülkeye ihraç edilmektedir. Sektörde aşağı yukarı 15.000 bayi ile 3.500 yetkili servis ve 500 civarında da tedarikçi bulunmaktadır (Öztürk, 2016: 14).

\subsection{Türkiye'de Beyaz Eşya Sanayii Talebini Etkileyen Unsurlar}

Beyaz eşya sanayii yeni ürünlere ve çoğu yenileme amaçlı satışlara bağlı olan dönemsel bir endüstridir. Farklı ürün kategorileri için doygunluk seviyeleri oldukça istikrarlıdır. Fakat ekonomik dönemlere göre tüketici taleplerinin değişiklik arz ettiği bir yapıya sahiptir. Örneğin, durgunluk dönemlerinde bu talepler ertelenebilmektedir. Ayrıca satışı etkileyen diğer faktörler arasında yeni konut 
inşası, evlerin yeniden dekorasyonu, faiz oranları, istihdam ve tüketici güveni yer almaktadır (https://www.scribd.com/document/168101608/2006-Household-Appliance-Industry, 10.07.2019).

Beyaz eşya sektöründe talebin oluşmasında önemli rol oynayan en önemli değişkenler ve bunların sektörde satışları arttırma potansiyeline ilişkin yansımaları şu şekilde sıralamak mümkündür (IZTO, 2001: 10-11; Öztürk, 2016: 24-27; Avc1oğlu, Özata, Nirun ve Gürel 2018: 8-9):

Gayri Safi Milli Hasıladaki Artışlar: Uzun bir trend çerçevesinde tüketici gelirlerinde gözlenen artışlar, tüketici ihtiyaçlarının çeşitlenmesine ve yeni ihtiyaçların oluşmasına neden olacağı gayet açıktır. Bu olgu, tüketicilerin daha önce kullanmadıkları bazı yeni araçları talep eder duruma gelmelerine neden olmaktadır.

Konut Satışlarındaki Artış: Beyaz eşya talebinin önemli bölümü konut satışlarına paralel olarak gerçekleşen yeni beyaz eşya talebinden kaynaklanmaktadır. 2017 yılında önceki yıla göre \%5,1 artan konut satışlarının ve Kentsel Dönüşüm Programı kapsamında 6,5 milyon konutun yenilenmesi söz konusu olduğundan beyaz eşya sektörüne olumlu etkisi devam edeceği beklenmektedir.

Kampanyalı Satışlar: 1980'li yıllardan itibaren başlayan kampanyalı satışlar talebin artmasında önemli bir rol oynamıştır. Özellikle 1990 sonrasında ödeme sürelerinin uzun zaman dilimlerine ve vadeye yayılması, diğer taraftan kampanyaların yıl içerisinde çok sık tekrar edilir olması, orta ve düşük gelirli ailelerin satın alıcı duruma gelmesinde önemli rol oynamaktadır. Beyaz eşya satışlarının ağırlıklı olarak kredi kartıyla yapılması sonucu kartlı ödemelerle ilgili önlemler sektördeki satışları büyük oranda etkilemektedir. 2014 yılında beyaz eşya satışlarına getirilen 9 taksit sınırlaması satışlarda düşüşe sebep olduğundan daha sonra bu olumsuz etkiyi gidermek için sektör senetli satışlara yönelerek ve taksit kısıtının etkileri kontrol altına alınmıştır. Ayrıca Kasım 2015'den itibaren maksimum taksit sayısı yeniden 12 aya çıkarılmıştır. 2017 yılında beyaz eşya ürünlerinde \%6,7 olan ÖTV oranının \%0'a indirilmesi de talebin artmasını etkilemiştir.

Tüketici Kredileri ve Faiz Oranları: Bankaların son yıllarda uygulamaya başladıkları tüketici kredilerinden yararlanarak, bazı malları satın alabilme olanağının ortaya çıkması, dayanıklı tüketim mallarına olan talebin canlanmasında önemli bir rol oynamıştır. Bankaların bu alana ayırdıkları fonların büyüklüğü ve uyguladıkları faiz oranları talep düzeyi üzerinde belirleyici olmuştur.

Yeni Evlenmeler ve Boşanmalar: Türkiye'de yaz aylarının evlilik sezonu olması nedeniyle beyaz eşya satışları artmaktadır. Ayrıca evlenmelerle birlikte boşanmaların da artması beyaz eşya satışlarına olumlu etki yapmaktadır.

Elektrifikasyon ve Su Sorununun Çözümlenmesi: Son yıllarda özellikle kırsal kesimde gerçekleştirilen yoğun elektrifikasyon ve köylere içme suyu götürme çalışmaları sonucunda köylerimizin tamamına yakın kısmı elektriğe ve büyük bir kısmı da basınçlı suya kavuşmuş durumdadır. Modern araçlardan yararlanabilme olanağının ortaya çıkması kırsal kesimden önemli bir beyaz eşya talebinin ortaya çıkmasına neden olmaktadır. 
Kadının Konumu: Çalışan kadın sayısında gözlenen artışlar, kadının aile kararlarına daha etkin olarak katılması, hayatı kolaylaştırıcı ve zamandan tasarruf sağlayıcı araçlardan yararlanma isteği, elektrikli ev araçlarına olan talebin artmasına katkıda bulunmaktadır.

Şehirleşme: Kırsal-kentsel kesim, nüfus dağılımında kentsel nüfus lehine gözlenen hızlı değişim ve buna bağlı olarak şehirli nüfusun modern yaşamdan yararlanma isteği, büyük şehirlerin çevresinde yer alan gecekondu nüfusunun beyaz eşya talebini körüklemektedir.

Aile Yapısında Değişme: Son yılların sosyal yaşamımızda yarattığı önemli bir değişme de geleneksel büyük aile tipinin yerini çekirdek aileye bırakması şeklinde ortaya çıkmaktadır. Bu durum yeni bağımsız aile sayısının artması sonucu dayanıklı tüketim mallarının talebini arttırmaktadır.

Yenileme Talebi: Her malın olduğu gibi, dayanıklı tüketim mallarının da kendine özgü ortalama fiziki ömürleri mevcuttur. Bu süre, örneğin buzdolabında 15-20 yıl, çamaşır makinelerinde 10-15 yıl olarak hesaplanmaktaydı. Ancak, 90'lı yıllara kadar buzdolabı, çamaşır makinesi ve firın gibi beyaz eşya kullanım süreleri 10-15 yıl kadarken, 2000’li yıllarda 10, hatta 7 yıla kadar gerilemiş bulunmaktadır. Dayanıklı tüketim mallarında sahiplik oranı artıp, pazar doydukça, yenileme talebinin payının yükseleceği kaçınılmaz bir durumdur. Ayrıca firmaların pazara sundukları daha modern, ihtiyaçlara daha iyi cevap veren ürünlerin ve çeşit sayısının artması da bu yenileme talebinin öne alınmasında ve talebin ivme kazanmasında etkili olmaktadır. Dolayısıyla tüketiciler ellerindeki ürünü, teknolojisi daha iyi ve yeni olanlarla değiştirmeye başladığından, Türk evlerindeki eşya parkı gençleşmektedir.

\subsection{Türk Beyaz Eşya Sanayiinin Ekonomik Profili}

Türk Beyaz eşya sanayiinin üretimi 2014-2018 yılları arasında yaklaşık her yıl \% 7- 9 aralığında artış göstermiştir. Yapılan üretimin yaklaşı \% 25-30'u da iç satışa gider iken \% 70-75'i de ihraç edilmiştir. Son beş yılın ihracat ve ithalat miktarları incelendiğinde ithalatın çok da artmadığı görülmektedir. İthalatın ihracata oranı ortalama \%5’lerde gerçekleşmiştir. Bunun en önemli nedeni olarak yerli üreticiler tarafından dünya pazarının tüm gereklerinin ürün çeşitliliği, kalite, fiyat vb. faktörler açısından yerine getirildiği ve ithal ürünlerle farkların azaldığı söylenebilir (Tablo 2).

Tablo 2. 2014 - 2018 Dönemi Türk Beyaz Eşya Sanayii'nin Üretim, İç Satış, İhracat ve Ithalat Rakamları (Adet)

\begin{tabular}{|c|l|l|l|l|l|}
\hline Ylllar & \multicolumn{1}{|c|}{$\mathbf{2 0 1 4}$} & \multicolumn{1}{|c|}{$\mathbf{2 0 1 5}$} & \multicolumn{1}{|c|}{$\mathbf{2 0 1 6}$} & \multicolumn{1}{|c|}{$\mathbf{2 0 1 7}$} & \multicolumn{1}{|c|}{$\mathbf{2 0 1 8}$} \\
\hline Üretim & 22.595 .875 & 24.563 .133 & 26.236 .181 & 28.432 .103 & 28.538 .758 \\
\hline İç Satış & 6.706 .437 & 7.090 .051 & 7.469 .796 & 8.533 .013 & 7.110 .193 \\
\hline İhracat & 16.903 .600 & 18.082 .490 & 19.547 .508 & 20.639 .701 & 22.092 .563 \\
\hline İthalat & 820.557 & 941.689 & 855.773 & 1.103 .133 & 626.085 \\
\hline
\end{tabular}

Kaynak: TÜRKBESD, http://www.turkbesd.org/bilgiler.php?P=22, 15.07.2019 
Üretimin yaklaşı \% 75'i ihracata yönelik olan ve ihracatının tamamına yakınını AB ülkelerine gerçekleştiren beyaz eşya sanayiinde 2017 yllında iç piyasadaki teşvikler ile öne çekilen talep sayesinde iç talepte büyüme yaşanırken, ihracat 2016 yılına benzer seviyede gerçekleşmiştir. Küresel ihracatta yaşanan gerilemeye paralel şekilde (Tablo 1) Türkiye beyaz eşya sektörünün de ihracat miktar ve tutarlarında çok fazla olmamakla birlikte bir yavaşlama eğilimi söz konudur (Tablo 2 ve Tablo 3 ).

İhracata ürün bazında bakıldığında hem adet hem de tutar açısından ev tipi buzdolapları ve ev tipi çamaşır makinelerinin önde geldiği görülmektedir.

Tablo 3. Türk Beyaz Eşya Sanayii Ürünleri İhracat Değerleri (\$)

\begin{tabular}{|c|l|c|c|c|c|}
\hline Yıllar & $\begin{array}{c}\text { Ev Tipi } \\
\text { Buzdolapları }\end{array}$ & $\begin{array}{c}\text { Ev Tipi Derin } \\
\text { Dondurucular }\end{array}$ & $\begin{array}{c}\text { Ev tipi } \\
\text { Çamaşır } \\
\text { Makineleri }\end{array}$ & $\begin{array}{c}\text { Ev Tipi } \\
\text { Bulaşık } \\
\text { Makineleri }\end{array}$ & $\begin{array}{c}\text { Toplam Beyaz } \\
\text { Eşya Sanayii } \\
\text { Ürünleri }\end{array}$ \\
\hline $\mathbf{2 0 0 8}$ & 957.105 .184 & 149.422 .424 & 666.447 .475 & 264.207 .561 & 2.854 .075 .358 \\
\hline $\mathbf{2 0 0 9}$ & 875.713 .098 & 174.585 .960 & 664.021 .018 & 280.942 .370 & 2.687 .352 .214 \\
\hline $\mathbf{2 0 1 0}$ & 954.912 .690 & 216.664 .965 & 664.345 .103 & 290.837 .037 & 2.969 .322 .301 \\
\hline $\mathbf{2 0 1 1}$ & 1.133 .680 .710 & 215.525 .773 & 684.446 .710 & 332.701 .462 & 3.386 .785 .763 \\
\hline $\mathbf{2 0 1 2}$ & 1.321 .017 .551 & 215.735 .693 & 691.926 .025 & 381.079 .046 & 3.746 .223 .288 \\
\hline $\mathbf{2 0 1 3}$ & 1.239 .179 .163 & 221.214 .889 & 759.854 .823 & 406.210 .606 & 3.845 .365 .276 \\
\hline $\mathbf{2 0 1 4}$ & 1.203 .955 .041 & 238.752 .911 & 870.684 .377 & 423.893 .502 & 4.116 .756 .712 \\
\hline $\mathbf{2 0 1 5}$ & 1.034 .059 .836 & 209.530 .619 & 872.066 .361 & 375.540 .231 & 3.702 .156 .022 \\
\hline $\mathbf{2 0 1 6}$ & 1.063 .132 .137 & 215.520 .830 & 904.737 .751 & 390.967 .339 & 3.755 .565 .312 \\
\hline $\mathbf{2 0 1 7}$ & 1.092 .944 .391 & 216.855 .107 & 931.362 .935 & 449.105 .949 & 3.954 .208 .726 \\
\hline
\end{tabular}

Kaynak: Birleşmiş Milletler'in verilerinden oluşturulmuştur. (https://comtrade.un.org/data/, 10.07.2019).

2014 y1lında Türkiye'de beyaz eşya üretimi 22,6 milyon adet iken 2018 yılında 28,5 milyon adede ulaşmıştır (Tablo 2). Sektörde üretimin dörtte üçü başta $\mathrm{AB}$ ülkeleri olmak üzere yaklaşık 150 ülkeye ihraç edilmektedir. Sektörün büyümesinde şehirleşme oranının ve genç nüfusun artması ve inşaat sektöründeki hareketlilikle beraber, ihraç pazarlarındaki özellikle $\mathrm{AB}$ ülkelerindeki gelişmeler etkili olmaktadir.

Tablo 4. Türk Beyaz Eşya Sanayii Ürünleri İthalat Değerleri (\$)

\begin{tabular}{|l|l|l|l|l|c|}
\hline Yıllar & $\begin{array}{c}\text { Ev Tipi } \\
\text { Buzdolapları }\end{array}$ & $\begin{array}{c}\text { Ev Tipi Derin } \\
\text { Dondurucular }\end{array}$ & $\begin{array}{c}\text { Ev tipi } \\
\text { Çamaşır } \\
\text { Makineleri }\end{array}$ & $\begin{array}{c}\text { Ev Tipi } \\
\text { Bulaşık } \\
\text { Makineleri }\end{array}$ & $\begin{array}{c}\text { Toplam Beyaz } \\
\text { Eşya Sanayii } \\
\text { Ürünleri }\end{array}$ \\
\hline $\mathbf{2 0 0 8}$ & 71.515 .601 & 31.285 .575 & 70.811 .775 & 46.060 .705 & 900.090 .280 \\
\hline $\mathbf{2 0 0 9}$ & 61.032 .536 & 33.583 .488 & 85.556 .321 & 45.977 .782 & 731.782 .346 \\
\hline $\mathbf{2 0 1 0}$ & 73.683 .462 & 47.787 .419 & 111.963 .188 & 56.362 .601 & 930.125 .631 \\
\hline $\mathbf{2 0 1 1}$ & 111.693 .480 & 52.481 .020 & 178.548 .686 & 88.616 .824 & 1.171 .941 .305 \\
\hline $\mathbf{2 0 1 2}$ & 91.174 .206 & 61.453 .901 & 156.059 .185 & 72.158 .707 & 1.088 .494 .295 \\
\hline $\mathbf{2 0 1 3}$ & 100.417 .667 & 94.711 .868 & 155.112 .559 & 89.988 .547 & 1.317 .979 .394 \\
\hline $\mathbf{2 0 1 4}$ & 100.607 .472 & 62.183 .806 & 139.618 .605 & 70.556 .576 & 1.231 .705 .368 \\
\hline $\mathbf{2 0 1 5}$ & 93.365 .502 & 68.792 .663 & 114.339 .169 & 55.306 .270 & 1.083 .258 .117 \\
\hline $\mathbf{2 0 1 6}$ & 88.115 .471 & 80.297 .971 & 94.283 .251 & 44.331 .204 & 897.792 .083 \\
\hline $\mathbf{2 0 1 7}$ & 103.633 .921 & 91.039 .011 & 89.770 .097 & 44.764 .464 & 836.340 .284 \\
\hline
\end{tabular}

Kaynak: Birleşmiş Milletler'in verilerinden oluşturulmuştur. (https://comtrade.un.org/data/, 10.07.2019). 
2008 -2017 yılları arasındaki dönem incelendiğinde, tüketicilerin yerli markalara artan ilgisi nedeniyle, beyaz eşya ithalatında daralma eğiliminin devam ettiği görülmektedir. Söz konusu dönemin başında 2008 krizinin de etkisiyle yaklaşı 900 milyon ABD doları olan ithalat değeri 2011-2015 yılları arasında artış da gösterse 2017 yıl sonuna gelindiğinde 836 milyon ABD doları seviyesine kadar gerilemiştir (Tablo 4).

Türkiye'nin en çok AR-GE yatırımı yapılan ve en yüksek patent sayısına sahip olan teknoloji odaklı beyaz eşya sektörü yatırımlarına 2016 yılında açıklanan AR-GE reform paketinin destek olması beklenmektedir.

Sac ve plastik Beyaz eşya üretiminde en önemli maliyet unsuru olan hammaddelerdir. $\mathrm{Bu}$ hammaddelerin üretiminde kullanılan girdilerde ithalata bağımlılı̆̆ın yüksek olması sektör için kur riski oluştururken, hammadde fiyatlarındaki düşüş eğilimi ise firmaların kârlılıklarını olumlu yönde etkilemektedir (Öztürk, 2016: 38).

\section{REKABET GÜCÜ ve AÇIKLANMIȘ KARȘILAȘTIRMALI ÜSTÜNLÜKLER ENDEKSİ}

Çalışmanın bu bölümünde birçok araştırmaya konu olan ve farklı açılardan ele alınan "Rekabet Gücü” kavramı ve rekabet gücünü ölçme yöntemlerinden biri olan “Açıklanmış Karşılaştırmalı Üstünlükler Endeksi" ne değinilmiştir.

\subsection{Rekabet Gücü Kavramı}

Rekabet gücü, rekabet sürecinde rakiplerden birinin sonuca ulaşması ve sonuca ulaşma sürecinde diğer rakibine göre bir üstünlüğe sahip olmasıdır. Bu bağlamda rekabet gücünün genel tanımı, birey, firma, endüstri, ülke, bölge gibi bir iktisadi birimin, veri başlangıç koşullarına göre, belirlenen amaçlara ulaşma süreci ve sonucundaki hedef göstergeler açısından rakiplerine göre üstünlüğe sahip olması şeklinde yapılabilir (Sarıdoğan, 2010: 7).

Rekabet gücü farklı bakış açılarıyla birçok araştırmaya konu olmuştur. Ancak iktisatçıların henüz üzerinde anlaştıkları tek bir rekabet gücü kavramı tanımı da bulunmamaktadır. Bunun nedenleri şöyledir (Düzgün, 2007: 423):

- Rekabet gücü firma, sektör ve ülke bazında her bir düzey için farklı tanımlanabilir.

- Rekabet gücünü belirlemede kullanılan ölçütler farkl1lık gösterebileceğinden; ülkenin sadece dış ticaret açısından rekabet gücü belirlenebileceği gibi çok sayıda gösterge ele alınarak ülkenin bütün olarak rekabet gücü de belirlenebilir.

- Rekabet gücüne mikro ya da makro açılardan bakılabilir.

Rekabet gücü kavramı genel olarak firma, endüstri ve uluslararası (ulusal) olmak üzere üç farklı düzeyde ele alınmakta ve tanımlanmaktadır (Aktan ve Vural, 2004: 11-16). 
- Firma düzeyinde rekabet gücü, herhangi bir firmanın ulusal ya da uluslararası piyasalarda rakiplerine göre daha düşük maliyetle üretimde bulunabilmesi, sunulan hizmet veya ürünün çekiciliği ve ürün kalitesi gibi unsurlar açısından rakiplerine eşit ya da daha yüksek bir seviyede olması ve ayrıca yenilik ve icat yapabilme yeteneğine sahip olması şeklinde tanımlanmaktadır.

- Endüstriyel rekabet gücü, bir endüstrinin rakiplerine eşit ya da daha üst düzeyde bir verimlilik düzeyine ulaşması ve bu düzeyi sürdürme yeteneği veya rakiplerine kıyasla eşit veya daha düşük maliyette ürün üretme ve satma yeteneğine sahip olmasıdır.

- Ulusal (uluslararası) rekabet gücü ise bir ülkenin, serbest ve adil piyasa koşulları altında, uzun vadede halkının reel gelirini artırırken, uluslararası piyasaların koşullarına ve standartlarına uygun mal ve hizmetleri üretebilme yeteneğine sahip olması şeklinde ifade edilmektedir.

Firmaların, endüstrinin, bölgenin, ülkenin ya da ekonomik entegrasyonların uluslararası rekabette nispi olarak daha yüksek gelir ve istihdam seviyesindeki üretim gücünü anlatan rekabet gücü, başka bir ifadeyle bir ülkenin ürettiği mallarda rakip ülkelerin malları ile fiyat, güvenilirlik kalite, tasarım ve zamanında teslim gibi unsurlarda yarışabilir düzeyde olmasıdır (Demir, 2001: 46).

Firma düzeyinde, endüstri düzeyinde ve ulusal seviyede rekabet gücünü ölçmek amaciyla geliştirilen çeşitli hesaplama yöntemlerinde kullanılan değişkenler, rekabet gücü üzerinde etkili olduğu düşünülen ekonomik göstergelerden oluşmaktadır.

Bu çalışmada Türk Beyaz Eşya Sanayii'nin Rekabet gücü Balassa tarafından geliştirilmiş Açıklanmış Karşılaştırmalı Üstünlükler (AKÜ) Endeksine göre analiz edilecektir.

\section{2. Açıklanmış Karşılaştırmalı Üstünlükler (AKÜ) Endeksi}

Ülkeler, dış ticareti sahip oldukları karşılaştırmalı üstünlüklere dayalı olarak yaparlar. Karşılaştırmalı üstünlüklerin zaman içinde gösterdiği değişim dış ticaret verileri ile açıklanabilmektedir. Ticaret öncesi göreli fiyatların bilinmemesi nedeni ile ülkelerin uluslararası alanda rekabet güçlerini belirleyen karşılaştırmalı üstünlükleri ölçmek zordur. Bir ülkenin rekabet gücünü belirleyen en önemli faktörlerden biri dış ticaret göstergeleridir. Bu sebeple açıklanmış karşılaştırmalı üstünlükleri belirlemek amacıyla, gerçekleşen dış ticaret verilerine dayanan AKÜ endeksi kullanılmaktadır (Yalçınkaya, Çılbant, Erataş Sönmez ve Hartoğlu, 2014: 49).

Rekabet gücünü ölçmeye yönelik yaklaşımlar arasında AKÜ endeksi en çok tercih edilen ve bu alanda yol gösteren yaklaşımdır. Ülkelerin belirli ürünlerdeki göreli ihracat performanslarını belirlemeye çalışan bu yaklaşım, ilk olarak 1958 yılında Liesner tarafından AKÜ endeksi ile ortaya konmuş ve daha sonra da Balassa tarafından geliştirilmiştir. Karşılaştırmalı üstünlüğün gerçek biçiminin, ticaret sonrası verilerden elde edileceğini varsayan AKÜ yaklaşımının asıl amacı, karşılaştırmalı üstünlüğün altında yatan faktörleri belirlemektense ülkenin karş1laştırmalı üstünlüğe sahip olup olmadığının belirlenmesidir (Baltacı, Burgazoğlu ve Kılıç, 2012: 8). 
Balassa'nın geliştirdiği AKÜ endeksi (1965) şu şekilde ifade edilebilir:

$\mathrm{AKÜ}=(\mathrm{Xij} / \mathrm{Xit}) /(\mathrm{Xnj} / \mathrm{Xnt})=(\mathrm{Xij} / \mathrm{Xnj}) /(\mathrm{Xit} / \mathrm{Xnt})$

Burada X ihracatı, i bir ülkeyi, j bir malı (ya da sektörü), t mallar (ya da sektörler) grubunu ve $n$ ülkeler grubunu (ya da dünya ülkelerini) göstermektedir. Bu doğrultuda AKÜ, belirli bir ülkenin belirli bir ürün ya da endüstrisinin ihracatının ülkenin toplam ihracatı içindeki payının, aynı ürün ya da endüstrinin bir ülke grubunun ya da dünyanın toplam ticareti içindeki payına oranlanması ile ölçülmektedir. Hesaplanan endeks değerinin 1'den büyük (AKÜ>1) çıkması durumunda, ülkenin ilgili alanda karşılaştırmalı üstünlüğe sahip olduğu kabul edilmektedir. Hesaplanan endeks değerinin 1'den küçük $(\mathrm{AKÜ<1)}$ çıkması durumunda ise, ilgili ülkenin o malın üretiminde rekabet gücünden yoksun olduğu düşünülmektedir (Fertö and Hubbard, 2002: 5; Yue and Ping, 2002: 278; Utkulu ve Seymen, 2004: 8-9).

AKÜ katsayısı ihracat verileri dikkate alınarak ölçüldüğü için daha güvenilir kabul edilmektedir. Az sayıda ürün ihraç eden ülkelerde, AKÜ katsayılarının yüksek çıkması, her zaman o ülkelerin rekabet gücüne sahip oldukları anlamına gelmemektedir. İhracat teşviklerinin olması durumunda da, bu katsayılar gerçekte olması gerekenden yüksek çıkar. Bu durumlara rağmen AKÜ katsayısı yine de daha sağl1klı sonuçlar vermektedir. Çünkü genellikle ithal ürünler üzerine gümrük vergileri konulduğundan, serbest ticaretin olmadığı az gelişmiş ülkelerin rekabet düzeyini daha gerçekçi açıklamaktadır (Demir, 2001;51).

\section{6- AKÜ’YE GÖRE TÜRK BEYAZ EŞYA SANAYIIINIIN REKABET GÜCÜ}

Türk beyaz eşya sanayiinin uluslararası başarısını incelemek için kullanılan temel ölçü AKÜ Endeksi ve bu endekse dayalı dünya ihracat paylarıdır. Bu endekste genel olarak Türk beyaz eşya sanayiindeki değişime baktı̆̆ımızda 2008 - 2017 döneminde toplam ve tüm ürün grupları için endeks değerlerinin 1'den büyük olduğu görülmektedir (Tablo 5).

Türk beyaz eşya sanayii 1990'ların başından itibaren Türkiye ekonomisinin göreli olarak daha rekabetçi sektörleri arasında yer almaktadır. Türk beyaz eşya sanayiinin 1995 - 2007 dönemi için AKÜ Endeks değeri ortalama 3 olarak hesaplanmış ve $3>1$ 'i olduğundan uluslararası rekabet gücü olan bir sektör olduğu görülmektedir (Akiş, 2008: 188-196). 
Tablo 5. Türk Beyaz Eşya Sanayii Ürünlerinin AKÜ’ye Göre Rekabet Gücü (1995 -2007)

\begin{tabular}{|c|c|c|c|c|c|}
\hline Yıllar & $\begin{array}{c}\text { Ev Tipi } \\
\text { Buzdolapları }\end{array}$ & $\begin{array}{c}\text { Ev Tipi Derin } \\
\text { Dondurucular }\end{array}$ & $\begin{array}{c}\text { Ev tipi } \\
\text { Çamaşır } \\
\text { Makineleri }\end{array}$ & $\begin{array}{c}\text { Ev Tipi } \\
\text { Bulaşık } \\
\text { Makineleri }\end{array}$ & $\begin{array}{c}\text { Toplam } \\
\text { Beyaz Eşya } \\
\text { Sanayii } \\
\text { Ürünleri }\end{array}$ \\
\hline $\mathbf{1 9 9 5}$ & 6,54 & 1,28 & 0,49 & 0,16 & 1,79 \\
\hline $\mathbf{1 9 9 6}$ & 5,18 & 2,25 & 0,62 & 0,29 & 1,83 \\
\hline $\mathbf{1 9 9 7}$ & 5,06 & 2,27 & 0,8 & 3,22 & 1,97 \\
\hline $\mathbf{1 9 9 8}$ & 5,09 & 3,53 & 1,1 & 2,51 & 2,09 \\
\hline $\mathbf{1 9 9 9}$ & 6,15 & 4,48 & 1,61 & 2,41 & 2,32 \\
\hline $\mathbf{2 0 0 0}$ & 6,11 & 4,1 & 2,38 & 2,17 & 2,56 \\
\hline $\mathbf{2 0 0 1}$ & 5,96 & 4,01 & 2,82 & 1,34 & 2,53 \\
\hline $\mathbf{2 0 0 2}$ & 7,45 & 4,61 & 5,05 & 2,52 & 3,06 \\
\hline $\mathbf{2 0 0 3}$ & 8,79 & 5,04 & 6,28 & 3,33 & 3,6 \\
\hline $\mathbf{2 0 0 4}$ & 7,81 & 6,33 & 7,15 & 3 & 3,51 \\
\hline $\mathbf{2 0 0 5}$ & 8,6 & 6,48 & 7,69 & 3,58 & 3,72 \\
\hline $\mathbf{2 0 0 6}$ & 4,93 & 3,28 & 4,54 & 0,79 & 4,51 \\
\hline $\mathbf{2 0 0 7}$ & 3,42 & 3,49 & 4,16 & 0,09 & 4,85 \\
\hline
\end{tabular}

Kaynak: Akiş, 2008: 190-195

1995 - 2007 yılarını kapsayan 13 yıllık dönem incelendiğinde ev tipi buzdolapları, derin dondurucular ve toplam beyaz eşya sanayiinin elde edilen AKÜ endeks değerleri kesintisiz şekilde 1'den büyük olduğu görülmektedir. Ev tipi buz dolapları 2007 yılı hariç hep ilk sırada gelmiş ve 2002-2005 yılları arasında en yüksek değere ulaşmıştır. Ev tipi çamaşır makinelerinin endeks değeri ise 1998 yılından sonra 1'den büyük gerçekleşmiş ve rekabet gücüne sahip bir ürün olmaya başlamıştır ve hatta 2007 y1lında diğer ürünlerden daha yüksek bir endeks değerine sahip olmuştur. Ev tipi bulaş1k makinelerinin endeks değeri 1997-2006 yılları arasında 1'den büyük iken diğer yıllarda 1'in altında kalmış ve bu dönemde en istikrarsız ürün olmuştur (Tablo 5).

Tablo 6. Türk Beyaz Eşya Sanayii Ürünlerinin AKÜ’ye Göre Rekabet Gücü (2008 -2017)

\begin{tabular}{|c|c|c|c|c|c|}
\hline Yıllar & $\begin{array}{c}\text { Ev Tipi } \\
\text { Buzdolapları }\end{array}$ & $\begin{array}{c}\text { Ev Tipi Derin } \\
\text { Dondurucular }\end{array}$ & $\begin{array}{c}\text { Ev tipi } \\
\text { Çamaşır } \\
\text { Makineleri }\end{array}$ & $\begin{array}{c}\text { Ev Tipi } \\
\text { Bulaşık } \\
\text { Makineleri }\end{array}$ & $\begin{array}{c}\text { Toplam } \\
\text { Beyaz Eşya } \\
\text { Ürünleri }\end{array}$ \\
\hline $\mathbf{2 0 0 8}$ & 7,57 & 7,47 & 8,07 & 8,99 & 4,05 \\
\hline $\mathbf{2 0 0 9}$ & 8,29 & 9,38 & 9,70 & 11,16 & 4,49 \\
\hline $\mathbf{2 0 1 0}$ & 8,56 & 11,72 & 10,09 & 12,07 & 4,75 \\
\hline $\mathbf{2 0 1 1}$ & 9,45 & 10,66 & 9,80 & 13,08 & 4,93 \\
\hline $\mathbf{2 0 1 2}$ & 9,73 & 9,08 & 8,81 & 13,96 & 4,76 \\
\hline $\mathbf{2 0 1 3}$ & 9,03 & 9,25 & 10,51 & 14,35 & 4,80 \\
\hline $\mathbf{2 0 1 4}$ & 8,29 & 9,21 & 11,35 & 14,13 & 4,72 \\
\hline $\mathbf{2 0 1 5}$ & 7,35 & 8,98 & 12,55 & 12,99 & 4,30 \\
\hline $\mathbf{2 0 1 6}$ & 7,47 & 9,03 & 12,74 & 12,73 & 4,24 \\
\hline $\mathbf{2 0 1 7}$ & 7,81 & 8,63 & 13,80 & 13,16 & 4,57 \\
\hline
\end{tabular}

Kaynak: Birleşmiş Milletler'in verilerinden oluşturulmuştur. (https://comtrade.un.org/data/, 10.07.2019). 
2008-2017 yılları arasında Türk beyaz eşya sanayiinin endeks değeri ortalama 4,5 olarak hesaplanmıştır. 1995-2007 dönemine göre endeks değerinin yükseldiği ve endüstri olarak hala uluslararası rekabet gücüne sahip olduğu görülmektedir. 1995-2007 yılları arasında en istikrarsız ürün olan Ev tipi Bulaşık makinelerinin endeks değeri 2008-2017 yılları arasında önceki 13 yıllık dönemin aksine ortalama 12,5 ile en yüksek değere sahip olmuştur. Ev tipi bulaşık makinelerini ev tipi çamaşır makinelerinin takip ettiği görülmektedir (Tablo 6). Buradan hareketle üreticilerin bu iki ürün grubunda önceki döneme göre eksikliklerini fark edip kendilerini geliştirdiklerini söylemek mümkündür.

\section{SONUÇ}

Küreselleşmenin sınır tanımadığı günümüzde firmaların, endüstrilerin ve ülkelerin varlıklarını sürdürebilmeleri ve yeni ekonomide başarıyı yakalayabilmelerinin sırrı rekabet gücü olarak karşımıza çıkmaktadır. Rekabet gücü; uzun dönemli büyüme elde etme, istihdam yaratma ve refahı arttırmak için ülkelerin, bölgelerin ve işletmelerin yeteneklerini nasıl yöneteceklerini belirleme amacını ifade etmektedir. Ülkeler birbirleri ile rekabet ettiğinde her ülke daha iyi bir konuma gelmektedir; bu nedenle rekabet gücü, kazanan ve kaybedenin olmadığı gelişmeyi sağlayan bir yol olarak tanımlanmaktadır. Rekabet avantajı ile elde edilen ekonomik büyüme, istihdamı ve üretimi arttırmakta ve karş1lı̆̆ında ekonomik kalkınmaya ve sosyal refah artışına neden olmaktadır. Bir ülkenin uluslararası alanda rekabet edebilirliği; mikro açıdan firmanın, makro açıdan da endüstrinin ve ülkenin rekabet gücüne bağlıdır.

Beyaz eşya sanayii ülke ekonomilerine önemli katkılar sağlayan katma değeri yüksek ürünler üreten bir sektör olduğu için, rekabet gücüne sahip olması, hem mikro hem de makro açıdan ülkenin rekabet gücü sıralamasında üst seviyelerde olmasını sağlayacaktır.

Türk beyaz eşya sektörünün 1990'l1 yılların başından beri AKÜ endeksine göre rekabet gücüne sahip olduğu görülmektedir. 1995-2007 ve 2008-2017 dönemleri arasındaki tek fark; 1995-2007 yılları arasında ev tipi buzdolapları ve derin dondurucular diğer ürünlere göre kesintisiz bir şekilde ve yüksek seviyede rekabet gücüne sahip iken, 2008-2017 yılları arasında ise ev tipi çamaşır ve bulaşık makinelerinin diğer ürünlere göre çok yüksek seviyede rekabet gücüne sahip oldukları görülmektedir. Yerli üreticiler tarafından küresel pazarın tüm gereklerinin fiyat, kalite, ürün çeşitliliği vb. faktörler açısından yerine getirilmesi ve ithal ürünlerle benzerliklerin artması bu durumun en önemli nedenlerindendir.

Türkiye'nin geneline göre yüksek katma değer yaratan ve daha rekabetçi olan beyaz eşya sektörünün üretiminde artık uzun vadede sanayi 4.0 dönüşümüne uyumu ve talep tarafındaki trendleri takip edebilme kabiliyeti önemli olacaktır. Üreticilerin Sanayi 4.0'a yönelik dönüşüm çalışmaları ve süreçlerini geliştirmeleri beyaz eşya sektörünün rekabet gücünü daha da arttıracaktır. Bu kapsamda üreticiler tarafından sektörün geleceğini belirleyecek trendlerden biri olarak görülen nesnelerin interneti uygulamalarıyla ürün geliştirme çalışmaları sürmektedir. Bağlantılı ve akıllı evler bu çalışmaların başını 
çekmektedir. Ayrıca artan çevre bilinci ve değişen zorunlu ürün standartlarıyla birlikte enerji verimliliği yüksek ürünler tüketiciler tarafından talep edilmektedir.

\section{KAYNAKÇA}

Akiş, E. (2008) “Küreselleşme Sürecinde Türkiye'nin Uluslararası Rekabet Gücü: Türk Beyaz Eşya Sanayii İçin Bir Uygulama”, Doktora Tezi, İstanbul Üniversitesi, Sosyal Bilimler Enstitüsü, İstanbul.

Aktan, C. ve Vural, İ.Y. (2004) "Rekabet Gücü ve Rekabet Stratejileri”, TİSK Yayınları No: 254, Ankara.

Avcıŏlu, C., Özata, F., Nirun, H. ve Soyuer Gürlü, Ö. (2018). Beyaz Eşya Sektörü, Türkiye Sınai Kalkınma Bankas1, İstanbul. (http://www.tskb.com.tr/i/assets/document/pdf/beyaz-esya-sektorelgorunum-subat-2018.pdf, 15.07.2019)

Balassa, B. (1965) "Trade Liberalisationand Revealed Comparative Advantage", The Manchester School of Economic and Social Studies, 33: 105-107.

Baltacı, A., Burgazoğlu, H. ve Kılıç, S., (2012), “Türkiye'nin Rekabetçi Sektörleri ve Trakya Bölgesi’nin Payı” Çankırı Karatekin Üniversitesi İktisadi ve İdari Bilimler Fakültesi Dergisi, $1(2): 19$

Demir, İ. (2001) “Türkiye Beyaz Eşya Sanayinin Rekabet Gücü ve Geleceği”, DPT, Yayınları No: 2571, Ankara.

Düzgün, R., (2007) Türkiye'nin Uluslararası Rekabet Gücü, Çok Değişkenli İstatistiksel Bir Analiz, Erciyes Üniversitesi Sosyal Bilimler Enstitüsü Dergisi, Say1: 23/2, Kayseri, pp.421-440.

Fertö I. and Hubbard L. J. (2002) "Revealed Comparative Advantage and Competitiveness in Hungarian Agri-Food Sectors Technology Foresight in Hungary ”, KTK/IE Discussion Papers 2002/8 Institute of Economics Hungarian Academy of Sciences.

İTO (2001) “Teknoloji ve Pazarlama Yapıları Değişirken Beyaz Eşya”, İzmir.

Öz, Ö. ve Pamuksuz, M.K. (2003). "Understanding Competittiveness: The Case of The Turkish White Goods Industry”, European Applied Business Research Conference, Venice, Italy.

Öztaşkın, R. (2007), : “Beyaz Eşya Sanayii Raporu”, DPT Yayınları No: 2756 - ÖİK: 700), Ankara. Öztürk, A. B. (2016). Beyaz Eşya Sektörü, Türkiye İş Bankası, İstanbul.

Sarıdoğan, E., (2010). "Mikroekonomi ve Makroekonomi Düzeyinde Küresel Rekabet Gücünü Etkileyen Faktörler ve Startejiler”, İstanbul, İTO Yayın No: 2010-51. 
Utkulu, U. ve Seymen D. (2004) "Revealed Comparative Advantage and Competitiveness: Evidence for Turkey vis-à-vis the EU/15”, European Trade Study Group 6th Annual Conference, ETSG 2004, Nottingham.

Yalçınkaya, M. H., Çılbant, C., Erataş Sönmez, F. ve Hartoğlu, D. (2014), “Açıklanmış Karşılaştırmalı Üstünlükler Endeksinde Rekabet Gücünün Analizi: Türk-Çin Dış Ticareti Üzerine Bir Uygulama", Yönetim ve Ekonomi Araştırmaları Dergisi, 24: 41-57.

Yue, C. and Ping H., (2002) “Does Comparative Advantage Explain Export Patterns in China?", China Economic Review, 13: 276-296.

https://comtrade.un.org/pb/data/, (10.07.2019).

https://www.scribd.com/document/168101608/2006-Household-Appliance-Industry, 10.07.2019. http://www.turkbesd.org/uyeler.php, (15.07.2019)

http://www.turkbesd.org/bilgiler.php, 15.07.2019). 